\title{
The therapeutic journey of families of children with respiratory diseases in the public health service ${ }^{1}$
}

\author{
Beatriz Rosana Gonçalves de Oliveira² \\ Neusa Collet ${ }^{3}$ \\ Débora Falleiros de Mello ${ }^{4}$ \\ Regina Aparecida Garcia de Lima $^{5}$
}

This study's purpose was to identify the therapeutic journey of families seeking health care for their children with respiratory diseases. This qualitative study had the participation of parents of children younger than five years old who were hospitalized with respiratory diseases. Path mapping was used as an instrument to collect data, which was analyzed through thematic analysis. The findings indicate that families sought the health services as soon as they perceived symptoms and had access to medical care, however such care was not decisive in resolving their health issues. Even though the families returned to the service at least another three times, the children had to be hospitalized. The attributes of primary health care were not observed in the public health services, while therapeutic encounters had no practical success.

Descriptors: Child Care; Primary Health Care; Respiratory Tract Diseases.

\footnotetext{
${ }_{1}^{1}$ Paper extracted from Doctoral Dissertation "Resolutividade do atendimento à saúde de crianças menores de cinco anos com queixa de doenças evitáveis", presented to Escola de Enfermagem de Ribeirão Preto, Universidade de São Paulo, WHO Collaborating Centre for Nursing Research Development, Brazil.

2 PhD, Professor, Universidade Estadual do Oeste do Paraná, Brazil.

${ }^{3} \mathrm{PhD}$, Adjunct Professor, Universidade Federal da Paraíba, Brazil.

${ }^{4}$ PhD, Associate Professor, Escola de Enfermagem de Ribeirão Preto, Universidade de São Paulo, WHO Collaborating Centre for Nursing Research Development, Brazil.

${ }^{5}$ PhD, Full Professor, Escola de Enfermagem de Ribeirão Preto, Universidade de São Paulo, WHO Collaborating Centre for Nursing Research Development, Brazil.
} 


\section{O itinerário terapêutico de famílias de crianças com doenças respiratórias no sistema público de saúde}

O objetivo deste estudo foi identificar o itinerário terapêutico de famílias em busca de cuidado para sua criança com doença respiratória. Trata-se de pesquisa sob abordagem qualitativa, com participação de familiares de crianças menores de cinco anos, hospitalizadas com doenças respiratórias. Utilizou-se como instrumento de produção de dados a dinâmica mapa falante, com análise temática dos dados. Os achados indicam que as famílias buscam um serviço de saúde assim que percebem os sintomas e que tiveram acesso a atendimento médico, embora com pouca resolutividade. Observou-se que retornaram ao serviço por pelo menos três vezes e que, mesmo assim, culminou com a hospitalização. Os atributos da atenção básica não foram contemplados nos serviços públicos de saúde, nem o encontro terapêutico obteve sucesso prático.

Descritores: Cuidado da Criança; Atenção Primária à Saúde; Doenças Respiratórias.

\section{El itinerario terapéutico de las familias de los niños con enfermedades respiratorias en el sistema de salud pública}

El estudio tuvo como objetivo identificar el itinerario terapéutico de las familias que buscan cuidar de su hijo con la enfermedad respiratoria. Esta es una investigación con un enfoque cualitativo, con la participación de las familias con niños menores de cinco años de edad, hospitalizados con enfermedades respiratorias. Fue utilizado como un instrumento de producción de los datos el mapa hablado, con una analice temática de los datos. Los resultados indican que las familias buscan un servicio de salud así que perciben los síntomas y que tenían acceso a la atención médica, pero con poca resolución. Se observó que volverán al servicio durante al menos tres veces, y aun así terminó con la hospitalización. Los atributos de la atención primaria no fueron observados en los servicios de salud pública, ni el encuentro tuvo un éxito práctico.

Descriptores: Cuidado del Niño; Atención Primaria de Salud; Enfermedades Respiratorias.

\section{Introduction}

Acute respiratory infections (ARI) persist as a public health problem. There is an estimated 0.29 clinical pneumonia events per child in developing countries, that is, 151.8 million new cases occur per year; $95 \%$ of the world incidence is observed among children younger than five years old. From $7 \%$ to $13 \%$ of cases result in hospitalization and more than two million result in death; pneumonia is the main isolated cause of death among children in this context. Brazil is one of the 15 countries with the largest number of cases of clinical pneumonia in children younger than five years old (1.8 million), with an estimated incidence of 0.11 events/child per year. ARI accounts for from $30 \%$ to $50 \%$ of ambulatory consultations, more than $50 \%$ of hospitalizations, and from $10 \%$ to $15 \%$ of deaths. $80 \%$ of these are due to pneumonia(1).

Respiratory diseases are considered Ambulatory Care Sensitive Conditions (ACSC), thus, hospitalization is avoidable ${ }^{(2-3)}$. Paradoxically, these conditions are listed as the most frequent cause of hospitalization. Pediatric protocols emphasize the importance of providing care to children within the family and community context, using its resources to promote health in routine ambulatory care ${ }^{(4)}$.

Primary Health Care (PHC) actions are important to preventing children from being affected by respiratory diseases through increasing coverage and ensuring the population access to services, and through delivering decisive ambulatory care to avoid hospitalization and its harmful consequences to children and their families. Studies ${ }^{(5-7)}$ have been conducted in several countries to improve the coverage of $\mathrm{PHC}$ in a horizontal care network to implement such actions.

Devising actions with this in mind implies guiding the nursing practice toward care, whether in health units guided by the Family Health Strategy (FHS) or traditional primary health care units, in order to overcome the exclusively technical and rational way of working 
and effectively intervene in problems and satisfy the social health needs of children ${ }^{(8)}$. This way of combining techniques and technologies to intervene in health problems is a way to organize the work process based on individual and/or collective needs.

From this perspective, care is seen as a caring attitude broadened to the totality of reflections and interventions in the health field. "A philosophical understanding and a practical attitude in relation to the meaning that health actions acquire in the various situations in which therapeutic action is required, that is, an interaction between two or among more individuals seeking to alleviate suffering or to achieve well being, always mediated by knowledge specifically focused on this purpose"(9).

When providing care, balancing procedures and care actions, the nurse establishes an intercessor relationship with the patient, and needs to incorporate attentive listening, conscientious reception of patients, bonding, responsabilization, to adopt practical rationality as a guide for actions in intersubjective care meetings ${ }^{(9)}$. It is expected that this study will contribute to the increase of knowledge concerning the care dimension of health workers.

Therefore, we seek to identify the therapeutic journey of families seeking care for children with respiratory diseases. We address the types of services sought, access, conscientious reception, integrality, bonding, and responsabilization of individuals, and whether the therapeutic encounter was focused on care.

\section{Method}

This qualitative study was guided by the Health Care theoretical framework ${ }^{(9)}$ and the methodological framework of hermeneutics in health(10-11). Data were collected through mapping ${ }^{(12)}$ the paths families followed up to the hospitalization. Six family members accompanying children with respiratory diseases (pneumonia, bronchopneumonia, pleural effusion, laryngitis, and pharyngitis) hospitalized in the pediatric hospitalization unit of a public hospital in the west of Paraná, Brazil participated in the study. This choice was based on the fact respiratory diseases are considered ACSC, that is, should not require hospitalization, and account for $50 \%$ of hospitalizations of children.

The inclusion criteria of family members were: having received prior care in the PHC services that compose the Brazilian Single Health System (SUS) in the city for the same reason of hospitalization; being resident of an urban area; the companion being in a condition to provide the information required by the study.

The following is assumed in this strategy of data collection: first - friendly reception of the participants in an organized environment; second - presenting and integrating the group; third - explaining the path mapping technique and its objectives and distributing material; fourth - developing the map and exposing the produced material to the remaining group members; fifth - collective analysis and validation of data, corresponding to the organization and preliminary analysis of data(10).

The group dynamics were surveyed twice, one for each group of family members meeting the inclusion criteria, in an appropriate room within the hospitalization unit. The groups were formed after the individuals agreed to participate in the study and the study's objectives were clarified for them. The question that triggered debate was: "What were the paths you have followed and what resources have been used to meet the health care needs of your children?" The path mapping dynamics were conducted in April and June 2010 and took two hours each. Discussions were recorded and the testimonies were transcribed and drawings were scanned.

We opted for the thematic analysis of data with the objective "to uncover core meanings composing the communication, the presence or regularity of which meant something for the analytical object" ${ }^{(13)}$. Hence, we discussed the two thematic units throughout the text: "access available to the first contact with services" and "longitudinality of care" without, however, presenting them separately or in watertight blocks. Rather, this discussion follows a hermeneutic of back and forth movement, addressing similarities and differences, to determine the whole experience concerning the journey of families in the search of care presented to the researcher.

The project was approved by the Ethics Research Committee at the State University of West Parana (UNIOESTE), protocol No. 245/2009 - CEP and the participants signed free and informed consent forms. The reports are identified as acronyms of the dynamic groups with a number added, e.g., map 1, companion 1 - M1C1.

\section{Results and Discussion}

\section{First contact with services and longitudinality of care}

The families considered the Primary Health Care (PHC) units, Family Health Units (FHU), and the Emergency Care Service (ECS) to be points of reference. The latter service provides care for urgent cases and emergencies referred by the PHC units.

The children were admitted due to respiratory problems after being cared for in PHC services: PHC units, FHU, ECS and private ambulatory services. Some sought these services more than once at different points in time, but all have in common the fact they went to the health 
unit in the first hours after respiratory symptoms and/or fever appeared.

The profile of the participant family members was: female family caregivers aged from 20 to 25 years old; children aged six months to three years old; the companions had between incomplete primary school to complete secondary school, while the latter was more frequent; domestic services and other positions in the service field were the most frequent occupations; only one woman had more than one child; all had a partner/spouse living with the family; the child's caregiver was the mother in most of the cases; the most frequent family income was two times the minimum wage; all had basic household appliances. These individuals had access to public services such as schools, daycare centers, health units, community centers and residents' associations, though they did not participate in the last two or in health councils.

The maps and the participants' testimonies concerning the path followed to seek care for their children are presented. M1C1 first sought the referral health unit in her neighborhood, then the emergency service and finally was referred to the hospital for the child to be hospitalized. The family sought the health unit seven times over an interval of 15 days.

[...] she already had fluid in her lungs before the influenza vaccine (H1N1), with a little cough. Right after she took the vaccine, a fever started, every day [...] I took her to the unit, the doctor was not giving consultations, the nurse told me to take her to the emergency service, Dr. M. prescribed her an inhaler using five drops of Berotec and sent her home. The employee at the drugstore said that five drops for her, who was only six months old, would be too much, because it'd speed up her breathing, it was too strong for her, it'd be bad; he said he couldn't oppose the opinion of the doctor but that was what he thought. We bought it, went home and did the inhalation with only saline solution. She didn't improve, we took her to the hospital, the first time to the university hospital, Dr. L said to put only two drops of Berotec in the inhaler and send us back home. Yesterday, I went to pick her up at the day care and the coordinator said she had a fever again, then I brought her here [...] they did some exams, and it has never changed, this time blood exam was a little changed, but they are not sure what it is because she had a fever (M1C1).

The first aspect to be discussed is the caregiver's belief that the vaccine caused the fever. She had talked to at least five different professionals, including physicians and nurses, but did not mention any orientation or guidance provided by health workers concerning potential side effects or even expected complications when this immunization is administered.

Then, when she sought the PHC unit as her primary option, she did not find the professional she wanted to assess the child and was informed by the nurse to seek the emergency service. From this time on, she did not go to the PHC unit anymore, instead she either went to the emergency service or directly to the hospital's ambulatory service. This conduct shows a rupture of bonds with the PHC unit and the impossibility of establishing new bonds with a health worker other than the physician, in this case the nurse, who through the use of broadened clinical tools could have assessed the child and included her in health care provided within the PHC unit in the event she needed another professional or even could have referred her to the care service she deemed appropriated within the network.

The health service users seek paths and services that enable them to satisfy their health needs ${ }^{(14)}$. Hence, it is not about seeking explanations of why the user goes to the emergency service or to the hospital or the reason that these may not be the most appropriate places to solve their health problem, but the point is rather in identifying the fact that the PHC unit and/or the FHU are not capable to appropriately receive this individual or provide appropriate follow-up to this individual's demands within a time period considered by the user to be tolerable.

Another aspect refers to the communication and bonds established between the physician and the caregiver. A relationship of trust was not established since the prescription was not followed after the pharmacy's employee questioned it. Therefore, the family abandoned the proposed therapy the first time it was questioned, since trust was not established with the health worker.

This breach of trust was reinforced a second time in the next medical consultation. The professional disagreed with the therapy initially proposed and changed it, which reinforced the rupture of trust in the professional who first examined the child in the emergency service. Again, however, a diagnosis was not established and the child went back home with the same symptoms that motivated the search for care in the first place. Since the demand had not been satisfied, the child returned to the service, this time with an aggravated clinical condition and had to be hospitalized.

The purpose of another study was to identify the accessibility to primary actions provided to children cared for in emergency services, reconstructing the family's journey from the initial contact with health units concerning the current event and characterizing the bonds established with the PHC services and how the morbidity fits the organizational profile of the services. Four possibilities of conflicts between the demand and supply of services were identified: the child would have an acute manifestation while the PHC unit was closed. In this case, the emergency service would be adequate; a conflict between the PHC unit's office hours and the work 
hours of parents, who then need to seek the emergency service; there would be a conflict with the service's organization, bonding between the user and the staff and/or professional, and/or expectations concerning the service's ability to meet immediate needs. Geographic access also might even be an impediment or hinder access to healthcare ${ }^{(15)}$. It seems that these possibilities, with the exception of the last one, which was not manifested by the family, were present in this process.

M2C2 sought care directly from the emergency service because her child has frequent respiratory crises and the PHC unit in her residence area only distributes tokens for consultations for the next week on Fridays. The $\mathrm{PHC}$ unit is not mentioned as a health service she usually seeks to provide care for her child because the bond has already been broken in other situations prior to this last hospitalization or was never established, whether because of limited access or because the user believes that the unit does not provide integral care or longitudinal care.

The following testimony describes the journey of this family in the search for care for its child:

It (the neighborhood unit) is like this: we have to go on Fridays to get a token, you have to be there and wait in line, the line is huge, only to get a consultation for the next week. When the child's breathing is affected, I go directly to the emergency service, I don't even go to the unit, because you have to get a token on Friday, it doesn't help to go there with a sick child asking for a consultation; they won't provide care to the child. [...] when he gets pretty sick, he's immediately cared for there (in the emergency service) [...] now, this is the second time that with Dr. D., I see my child is pretty sick and I already know I have to take him and get him admitted into the emergency service, and it's the second time I go there for a consultation, and this Dr. says: "I'll prescribe an inhaler, medication and you can go home because your child is well", then in the afternoon, I bring him again and he has to get on oxygen, it's the second time it has happened (M1C2).

The first thing to be noted is that the caregiver perceives the difficulty accessing the PHC unit in her neighborhood, that is, it works with a schedule for routine consultations. When the child is in an acute condition and it is not the day to get tokens for a visit, she does not even attempt to use the service. A barrier to access is imposed by the way the service is organized. Moreover, there is disconnection between the families' demands and the service offered by the unit because the mother believes her child has a chronic respiratory disorder, which has not yet been identified, and the service provided by the PHC unit is not consistent with a chronic condition.

One study shows that the way consultations and individual procedures are organized in the service along with a dichotomy between care and prevention, apparent in the consultation scheduling: the physician limits his/ her time to consultations and nurses limit their time to procedures. Care is provided to those who fit the supply of care while the remaining are referred to other services out of the system, as happened with this family ${ }^{(14)}$. These practices limit the appropriate reception of patients and reflect on emergency services.

The second aspect to be considered refers to a mismatch between what the caregiver expects as medical care and what actually occurs on the two occasions the family went to the emergency service for a medical consultation. There is a gap in the dialogue: one does not listen to the other, does not understand what is expected by the family caregiver as a project to produce happiness and does not employ practical rationality to achieve success in the therapeutic encounter ${ }^{(9)}$. Not only was there a rupture, but the caregiver also did not want a particular professional to be responsible for the care provided to her child.

[...] God bless me that I no longer need to get a consultation there, but if I get there and ask who the pediatrician is and they say it is Dr. D, I'll say I don't want her, this is the second time I end up here (hospital) because of her, because if she had hospitalized him earlier, I wouldn't have to put him here. (M1A2).

Problem-solving capacity in the primary health care service is linked to instrumental resources and the technical knowledge of professionals, as well as to a welcoming and conscientious reception of patients, to the bonds established with users, to the meaning assigned to the professional-user relationship, which suggests there is an encounter between individuals with the purpose of acting upon one's health and which was not observed in relation to this family in the various consultations. Low problem-solving capacity is also related to the hegemonic exercise of clinical care centered on the act of prescribing medication and the production of procedures(16). Hence, the clinical act translated in speech and listening, in which the diagnosis has the dimension of care, was replaced by an act in which prescription is the most important thing. The relationship of giving prescriptions is established in a brief relationship between the worker and user, illustrated in the testimony previously presented.

The map developed by M2C2 shows that the family first sought the PHC unit, then the emergency service, because an additional symptom was perceived by the family beyond the initial ones. After the consultation and therapy prescribed, the child was still symptomatic, indicating she was not well and the family decided to go to a private outpatient clinic, paying for the consultation and exams. The child was then referred to the emergency service, because the professional considered hospitalization to be required, and since the family could not afford it, the child was then referred to the public health service as shown in Figure 1. 


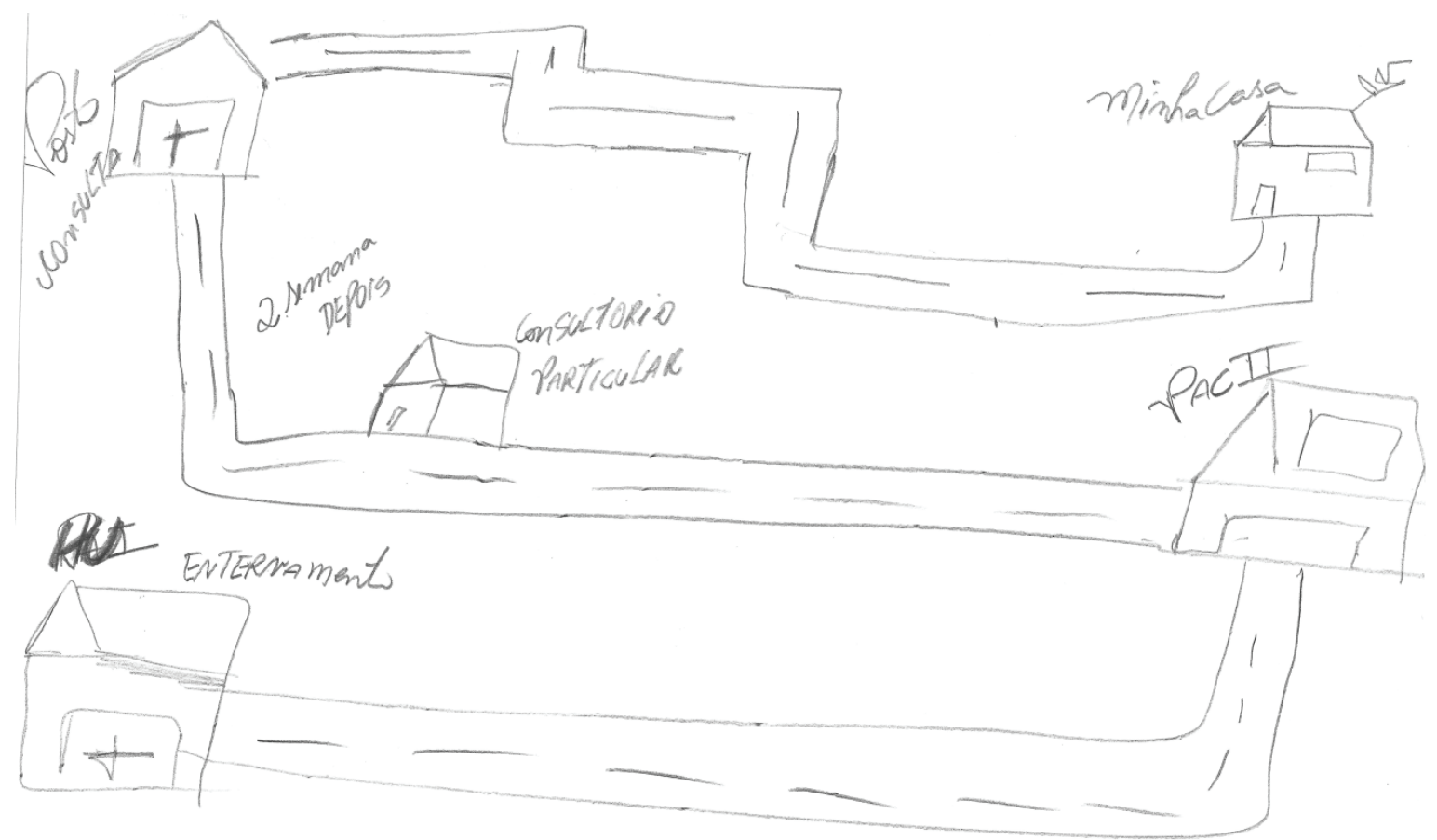

Figure 1 - Map produced by M2C1

The testimony reveals the family's feelings concerning the illness and the service's problem-solving capacity in relation to their care demands:

She had a temperature for days, the fever would come and go. I gave her medication, took her to the unit, the physician said her chest was full of fluid[...] she only gave medication for coughing, an inhaler, saline solution for her nose and medication to treat the fever. On Thursday she had fever again and started to moan, wouldn't eat, she acted like she was in pain, her ear started to ooze, so I took her to the emergency service. The Dr. asked for an X-ray, it was the beginning of pneumonia, but it was possible to treat her at home, he gave the medication, but it didn't work. On Monday I took her to a private doctor, he asked for an X-ray and said she had to be hospitalized, told me to go to the emergency service and $I$ went there again and showed them $X$-ray they took at the clinic [...] he then said he'd hospitalize the child [...] the entire week going to physicians and for medication (M2C1).

This testimony reports the way the various services have organized their work processes, focusing on the procedure instead of the patient. In all the places, whether in the PHC unit, private clinic or the emergency service, the priority was not on attentive listening nor interactive dialogue, rather the procedures seemed more important: the consultations, the exams, the various diagnoses, which show a discontinuity of care. Each service repeated the same procedures, even on the same day, $\mathrm{X}$-rays were taken in three different services to be evaluated by different professionals, without however, positively influencing problem-solving capacity. On the contrary, this entire journey only delayed the problem's identification.
The mismatch between the family and health workers is manifested when the family reports having sought the service right after the onset of the first symptoms. The proposed therapies did not solve the problem and the symptoms worsened over the period between the first consultation and eventual hospitalization without the professionals realizing the family's context and what it was experiencing. Questions such as how many times the family had gone to the service, which services it had visited, who had provided care, which therapies had been implemented, and whether these therapies had worked or not, were never asked or taken into account. To meet these demands, time and the disposition to listen is required, as well as the establishment of bonds with the family and child, co-responsabilization, problem-solving capacity, the empowerment of individuals to resume life with their health recovered, which did not happen in the different encounters experienced by this family.

In another testimony, M2C2 reports the family's comings and goings to the health services.

I took her to the unit about a month ago because the unit in my neighborhood doesn't have a pediatrician (a PHC unit with a generalist physician). The doctor gave her medication for fever and saline solution for her nose and said it was only a little cold. So, that cough was getting worse, I took her to the unit again as I realized treating her at home was not helping. She woke up crying on Sunday and would not stop crying, then started to throw up, there were secretions from her nose and some blood. I freaked out when she threw up, my husband took her to the emergency care II unit and there wasn't a pediatrician there, so they referred 
her to the emergency care I unit, where they took X-rays and said she had double pneumonia. They told me a lot of stuff and I got scared, sent me here to the university hospital, now she is under treatment, she's already much better. [...] the first time I went to the emergency service, she examined the baby and only listened to her lungs and prescribed a medication without making exams, taking an X-ray (M2C2).

We highlight the mismatch between the user's expectations and what the health service has offered as a technological care arrangement. The health provider to which this family refers is one unit in which two family health teams work. These are the only two teams in the urban area because the others are in the city's rural area. The population does not consider the health care provided by this unit to be decisive because of the way the work process is organized in the unit. The option chosen by the family represented here was to take the child to another unit with a pediatrician.

The literature ${ }^{(16)}$ reports that even though the FHS's mission is to change the care model in order to focus on the care of patients, access to services was not really simplified, especially in relation to what patients consider to be an emergency that requires immediate care, which in turn leads to low credibility for the service.

Another issue is related to the unit's scheduled practices such as child wellness visits. The user has not obtained access to the service since her child's birth because appointments were, for various reasons, scheduled and then unscheduled by the unit. The family considers there to be a lack of commitment on the part of the unit and the nurse in relation to the care that is supposed to be delivered, a fact that undermines any possibility of bonding between the family and the members of the health unit.

Even in the unit, she is four months old, there're been four months I've tried to schedule child wellness visits and they call me back cancelling the consultation: "the nurse is in a meeting, she's going to do this, to do that", I just don't have access to child wellness visits (M2C2).

Like this family, another family had this PHC unit as care reference. Among the situations reported, this one is emblematic because it shows that, even though the family lacks the means to pay for private health services, it no longer seeks care in the public healthcare services. It characterizes a rupture of bonds with public primary care; this is a discredit to the health provider from the view of the family.

She was complaining of ear pain last Sunday, I took her to the pediatrician in the (private) hospital on Monday, I paid for the consultation, she prescribed an antibiotic, because her ear was infected and asked for an $X$-ray because there was a little squeak in the chest. I took the X-ray on Tuesday and went to the doctor, she said she had a little phlegm in the lungs and prescribed antibiotics.
I gave the antibiotics at home and she had fever on Thursday, I took her to the doctor's office again, she took another $X$-ray and the Dr. said the secretions in her lung had doubled and sent me to the emergency service. I went to the emergency service, showed the $X$-rays to the physician there and he immediately sent me here. He said she had a very strong bacterium that had spread widely, they say names we don't understand much, so I became pretty scared (M2C3).

Among the aspects to be discussed in relation to the care provided to this family, we highlight the family member's comment concerning the dialogue established with the professional about the therapeutic action. The terminology used by the health worker was not properly understood by the family member who reported becoming "scared" over the child's health condition. The dichotomy between the professional's knowledge and that of the family member as the one who implements the therapy is apparent. Even though their knowledge is different, it is the role of the professional to deal with such knowledge and establish a dialogue to enable the caregiver to become autonomous, instead of using incomprehensible language.

The satisfaction of users concerning care provided in a PHC unit in Ribeirão Preto, SP, Brazil was analyzed in terms of three aspects: access, interaction between the staff and users, and the work organization within the unit. The studied individuals reported being satisfied with access as long as it is allied with conscientious care delivery. The family previously mentioned experienced a situation in which access was a problem due to the unit's office hours and the care delivered was not decisive(17).

Another study(18) analyzing the extent to which health workers composing FHS teams understand the humanization of care suggests providing education and qualifications to professionals, adjusting activities to the professionals' responsibilities, and improving the organization of services in order to improve care delivery. That is, similar to the families in this study who perceive barriers in the care delivery process, the professionals also perceive these barriers and suggest measures to attenuate them.

A study ${ }^{(19)}$ conducted from the perspective of conscientiously receiving patients and with the purpose to identify and analyze aspects concerning the preparedness of workers for the worker-user relationship in PHC units in a city in the state of São Paulo, Brazil verified that, theoretically, the availability of workers to prepare the environment, themselves, and the care relationship itself pervades the workers themselves (their affections, desires, projects) and also the context in which they exist. However, workers do not normally implement conscientious reception because they live troubled, hectic lives, expend a great amount of energy, and do not pause to reflect upon what they do. 
The report of families refer to the limited access imposed by the service's organization, e.g., office hours are the same as business hours, which coincides with the caregivers' work hours, impeding the family from taking the child for care in that unit. It is also surprising that access to the unit, which works with the family health strategy, is established through the distribution of consultation tokens, another factor limiting access to the service.

[...] I've already given up taking the child to the health unit, it's really hard getting a consultation, it has to be in the middle of the night, and there's this system I really don't get, it is distributed by area, they divided the neighborhood into two areas and put two doctors, one to give consultations to area one and another to give consultations to area two, if you're from area two and the physician there gives consultation to the area one, you won't get a consultation, regardless of the fact there is vacancy, sometimes there're tokens available but he doesn't give consultations, only to those from area one. It is also very difficult for those who work, it opens at 8am and close at 12pm, so it is closed during lunch hours, and if I'm not wrong, it closes at 5:30pm. The unit is closed when I have time to go there, so I don't even bother (M2C3).

We also highlight the difficulty reported by the family member concerning the way the FHS unit operates. It has two family health teams within the same physical area, dividing the covered area geographically. The family's report shows that the distribution of users, which should work as a factor bonding the community to the service, in reality works as an impediment to medical consultations.

\section{Final Considerations}

The PHC unit's qualitative deficiencies result in ACSC hospitalizations. The paths followed by the studied families demonstrate such a fact, that is, the symptoms were classified in the group of respiratory diseases, worsened, and resulted in the hospitalization of children, even after care delivery. To use hospitalizations as an indicator of the health system's effectiveness, they should be interpreted according to the technological arrangements of the work process organization that generate them, as a result of policies and actions implemented to solve health problems. Primary health care's attributes, specifically first contact access and longitudinal care, were not observed in these services while the therapeutic encounter did not obtain practical success.

Political commitments to the health of children, such as providing integral healthcare to common childhood diseases, the child health care agenda, and family health strategy, proposes actions to health services in order to grasp children in their growth and development, health and disease determinants in therapeutic processes, care actions, prevention, health recovery. However, transforming these propositions into daily actions implies being committed to transforming these propositions into action within the health services to definitively satisfy the health needs of children and their families.

Otherwise, the professional actions of physicians and nurses overlap and become pointless, in uncoordinated programs that do not provide integral care and do not consider the health and disease determinants of children. It is necessary to provide encounters with problemsolving capacity, overcoming the conception of action exclusively focused on meeting spontaneous demand by scheduling procedures, in order to provide effective, relational, dialogical care based on attentive listening. It is possible, from this perspective, to establish bonds, responsabilization, and autonomy in the production of primary health care for children, in order to implement the transformation required in health services routines and nursing practice.

\section{References}

1. Cardoso AM. A persistência das infecções respiratórias agudas como problema de saúde pública. Cad Saúde Pública. 2010;26(7):1270-1.

2. Perpetuo IHO, Wong LR. Atenção hospitalar por condições sensíveis à atenção ambulatorial (CSAA) e as mudanças no seu padrão etário: uma análise exploratória dos dados de Minas Gerais. In: $12^{\circ}$ Seminário sobre a Economia Mineira; 29 agosto - 01 setembro 2006; Diamantina, Minas Gerais. Diamantina; 2006.

3. Caminal HJ, Casanova MC. La evaluacion de la atencion primaria y las hospitalizaciones por ambulatory care sensitive conditions. Marco conceptual. Atención Primaria. 2003;31(1):61-5.

4. Garg A, Sarkar S, Marino M, Onie R, Solomon BS. Linking urban families to community resources in the context of pediatric primary care. Patient Educ Couns. $2010 ; 79(2): 251-4$.

5. Crampton P, Jatrana S, Lay-Yee R, Davis P. Exposure to primary medical care in New Zealand: number and duration of general practitioner visits. N Z Med J 2007;120(1256):s/p.

6. Bruner C, Fitzgerald C, Plaza C. Improving child health care through federal policy: an emerging opportunity. Issue Brief (Commonwealth Fund) 2008;46:1-7.

7. Pur A, Bohanec M, Lavrac N, Cestnik B. Primary health-care network monitoring: a hierarchical resource allocation modeling approach. Int J Health Plann Manage. 2010;25(2):119-35.

8. Matumoto S, Fortuna CM, Kawata LS, Mishima SM, Pereira MJB. Nurses' clinical practice in primary care: a process under construction. Rev. Latino-Am. Enfermagem. 2011;19(1):123-30. 
9. Ayres JRCM. Cuidado: trabalho e interação nas práticas de saúde. Rio de Janeiro: CEPESC/UERJ/IMS/ABRASCO; 2009. 10. Ayres JRCM. Uma concepção hermenêutica de saúde. PHYSIS: Rev. Saúde Coletiva 2007;17(1):43-62.

11. Ayres JRCM. Para comprender el sentido práctico de las acciones de salud: contribuciones de la Hermenéutica Filosófica. Salud Colectiva 2008;4(2):159-72.

12) Cabral IE. O método criativo e sensível: alternativa de pesquisa em enfermagem. In: Gauthier JHM, Cabral IE, Santos I, Tavares CMM. Pesquisa em enfermagem: novas metodologias aplicadas. Rio de Janeiro: Guanabara Koogan; 1998. p. 177-203.

13. Minayo MCS. O desafio do conhecimento: pesquisa qualitativa em saúde. $11^{\text {a }}$ ed. São Paulo: Hucitec; 2008.

14. Barros DM, Sá MC. O processo de trabalho em saúde e a produção do cuidado em uma unidade de saúde da família: limites ao acolhimento e reflexos no serviço de emergência. Ciênc Saúde Coletiva. 2010;15(5):2473-82.

15. Kovacs MH, Feliciano KVO, Sarinho SW, Veras AACA. Acessibilidade às ações básicas entre crianças atendidas em serviços de pronto-socorro. J Pediatr. 2005;81(3):251-8.

16. Franco TB, Mehry EE. Programa de saúde da família (PSF): contradições de um programa destinado à mudança do modelo tecnoassistencial. In: Mehry EE, Magalhães HM Júnior, Rimoli J, Franco TB, Bueno WS. O trabalho em saúde: olhando e experienciando o SUS no cotidiano. São Paulo: Hucitec; 2006. p. 55-124.

17. Mishima SM, Pereira FH, Matumoto S, Fortuna CM, Pereira MJB, Campos AC, et al. Assistance in family health from the perspective of users. Rev. Latino-Am. Enfermagem. 2010;18(3):436-43.

18. Marin MJS, Storniolo LV, Moravcik MY. Humanization of Care from the Perspective of the Family Health Strategy Teams in a City in the Interior of São Paulo, Brazil. Rev. Latino-Am. Enfermagem. 2010;18(4):763-9.

19. Matumoto S, Mishima AM, Fortuna CM, Pereira MJB, Almeida, MCP. Preparing the care relationship: a welcoming tool in health units. Rev. Latino-Am. Enfermagem. 2009;17(6):1001-8. 